\title{
THE EFFECT OF DIFFERENT LEVELS OF ORGANIC SELENIUM ON BROILER SLAUGHTER TRAITS**
}

\author{
Ž. Jokić ${ }^{1^{*}}$, Z. Pavlovski ${ }^{2}$, S. Mitrović ${ }^{1}$, V. Đermanović ${ }^{1}$ \\ ${ }^{1}$ Faculty of Agriculture, Zemun, Serbia \\ ${ }^{2}$ Institute for Animal Husbandry, Belgrade-Zemun, Serbia \\ Corresponding author: \\ *Živan Jokić, e-mail: zivjokic@agrifaculty.bg.ac.rs \\ ** Original scientific paper
}

\begin{abstract}
The effect of different levels of organic selenium (selenized yeast) on slaughter meat traits of fattening chickens (broilers) was investigated. Trial was carried out on 120 Hybro-PN chickens divided into four groups, in duration of six weeks. All groups of chickens were fed complete mixtures, and selenium was added to the food in the form of selenized yeast in the amount of 0 (I ); 0,3 (II); 0,6 (III) or 0,9mg/kg (IV-group).

The highest average values of carcass yield »conventional processing «, »ready to roast« and »ready to grill« were recorded in chickens of group III $(2059,6,1851,97$ and $1756,45 \mathrm{~g})$, with addition of $0,6 \mathrm{mg} \mathrm{Se} / \mathrm{kg}$, followed by chickens of group II $(2048,17,1841,36$ and $1748,57 \mathrm{~g})$ and group IV $(1957,46$, 1764,22 and $1676,05 \mathrm{~g}$ ) with 0,3 and $0,9 \mathrm{mg} / \mathrm{kg}$ of added selenium, respectively, whereas the lowest values $(1835,21,1660,87$ and $1572,61 \mathrm{~g})$ were established in chickens of group I without addition of this micro element.

Average values of slaughter yields »conventional processing «, »ready to roast « and »ready to grill« were approximately the same in chickens of all investigated groups, and established differences showed no statistical significance $(\mathrm{P}>0,05)$.

The lowest breast mass was in I group $(573,55 \mathrm{~g})$, and the highest in group III $(657 \mathrm{~g}$ ). Chickens of groups II and IV (with 0,3 and $0,9 \mathrm{mg} \mathrm{Se} / \mathrm{kg}$ of feed) realized breast mass of 627,90 and 633,12g. Compared to group I, average breast mass of chickens in groups III and IV was considerably higher $(\mathrm{P}<0,05$ and $\mathrm{P}<0,01$ ).

Share of breast in the mass of processed carcass was the highest in groups III and IV (37,40 and 37,86\%), and the lowest in group II (36,0\%). In chickens of group I the stated value was $36,47 \%$.

Average share of thighs in the mass of processed carcass was approximately the same in all investigated groups. The highest value $(14,4 \%)$
\end{abstract}


was established in chickens of group II, and the lowest (13,98\%), in chickens of III investigation group.

Chickens fed organic selenium in diet $(0,3,0,6$ and $0,9 \mathrm{mg} / \mathrm{kg})$ had by $3,80,3,74$ and $3,18 \%$ higher share of drumsticks in the mass of processed carcass compared to group I.

Key words: chickens, selenized yeast, slaughter properties

\section{Introduction}

Selenium has biological function only when it is incorporated into different selenoproteins. Fist discovered selenoprotein was enzyme glutathione peroxidase (GSH-Px) which contains this micro element in its active place (Rotruck et al., 1973). Selenium dependant glutathione peroxidase has the role to defend the cell system from damages induced by the effect of oxygen. Presence of oxygen and its radicals has detrimental effect on cells. Location of the effect of free radicals is mainly double bonds of unsaturated fatty acids, free or incorporated into cells. Free radicals come into contact with these acids, lead to rearranging of double bonds, and bonding of oxygen molecules leads to forming of peroxil radicals of fatty acid (ROO '). Subsequently, it attracts hydrogen from another molecule of unsaturated fatty acid forming hydroperoxide of unsaturated fatty acid $(\mathrm{ROOH})$ and new free radical. In this way a chain reaction occurs (Combs and Combs, 1986). Formed fatty acids are incorporated in cell membranes, disturb their function and destroy them. Activity of GSH-Px is different in individual organs, body fluids and subcell fractions (Hassan, 1987). Activity of glutathione peroxidase in poultry plasma is highly dependant on the level of selenium intake (Hugue and Jensen, 1985; Todorović, 1997; Todorović et al., 1999a). Activity of this enzyme varies considerably depending on the animal species and selenium status (Burk, 1983).

Recent investigations show that organic selenium increasingly suppresses the utilization of inorganic selenium (Mahan, 1999; Surai, 2000). Metabolic paths of the organic and inorganic selenium are different. Organic selenium is present in cereals, livestock feed and certain feed components, mainly in the form of selenomethionine, therefore its metabolic path is the same as methinone's. This is active transport through intestinal membrane and active accumulation in liver and muscle tissue (Surai, 1999). Recent results indicate that selenomethionine is not synthesized in animal or human organism, but it originates from plant sources. Inorganic selenium is retained for short time in tissues, incorporated slightly into selenoproteins, but large part of it is excreted 
by urine. Animal organism has adapted to organic selenium as main feed component, whereas the inorganic selenium is no natural source. Therefore it can be used as antioxidants occasionally (Surai, 2000). Organic selenium provides more efficiently selenium-tissue reserves compared to selenite. During movement of proteins and stress, selenomethionine is released into free amino acid reserves and can be used for forming of selenoproteins of glutathione peroxidase. This means that the animals under stress and in incubation period have adequate antioxidation protection preventing the decrease of production and reproduction performances.

In poultry production selenium is added to food mainly for the purpose of prevention of certain diseases by its positive effect on immunological system and increase if production characteristics, primarily body mass and more efficient utilization of food (Colnago et al., 1984; Todorović, 1990; Mihailović et al.,1991; Mahan, 1999; Combs, 1977, Jokić et al., 2005). There are numerous papers in literature presenting the investigation of the effect of different selenium sources and levels on quality of broiler meat (Downs, K.M., et al , 2000; Surai and Dvorska, 2002; Edens, 1996, 2001; Ahn et al., 1998; Džinić et al., 2006).

However, only few papers investigate the effect of selenium on slaughter properties of broiler meat. Edens (1997) established the correlation between vitamin $E$ and organic selenium and their effect on increase of dressing percentage in broilers. Similar results are stated also by Marković (2007), establishing that addition of organic selenium and vitamin E, beside the positive effect on carcass mass and meat yield of broilers, also increases the share of most valuable parts in their carcass. Similar conclusions were reached also by Naylor et al. (2000) and Payne and Southerm (2005) in their researches. They have established that inclusion of organic selenium in food for chickens in fattening increased the carcass mass, dressing percentage and mass and share of breasts in the mass of processed carcass.

Objective of this research was to investigate the effect of addition of different levels of organic selenium originating from selenized yeast on carcass yield and yield of certain carcass parts (breasts, thighs and drumsticks).

\section{Material and methods}

In trial 120 Hybro-PN chickens were used, divided into four groups (30 birds in each group). At the trial beginning chickens were weighed and marked with wing marks, and need for uniformity of groups was considered (I-group $36,17 \mathrm{~g}$; II-37,01g; III-37,16g and IV-36,59g). Fattening lasted 42 days and it was divided into three periods. In the first period (1-14th day) chickens were fed complete mixture with $23,01 \%$ of crude proteins and $12,95 \mathrm{MJ} / \mathrm{kg} \mathrm{ME}$, in the 
second period (15-35th day) with mixture containing $22,36 \%$ of crude protein and $13,38 \mathrm{MJ} / \mathrm{kg} \mathrm{ME}$, whereas in the third period (36-42nd day) mixture with $21,25 \%$ of crude protein and of energy value of $13,61 \mathrm{MJ} / \mathrm{kg}$ was used.

First group of chickens received mixture without added selenium. Other groups were fed mixtures in which 0,3 (II); 0,6 (III) and 0,9mg/kg (IV-group) of organic selenium in the form of selenized yeast was added.

At the end of trial on 42nd day, for the purpose of investigation of slaughter traits, 8 birds from each treatment were taken (4 males and 4 females). Chickens were slaughtered after 12 hour food deprivation, in order to eliminate the influence of outside factors on weight ratios. Processing of carcass was done according to methods of »conventional processing «, »ready to roast« and »ready to grill«. Yield of cooled carcasses or dressing percentage was calculated by establishing of relation of the mass of cooled carcass and weight prior to slaughtering.

Cooled carcasses were cut according to method laid down by the Rulebook on Quality of Poultry Meat (Official Journal of SFRY 1/81 and $51 / 88$ ) to main parts (thigh, drumstick, breast, wings, pelvis and back) and weighed on automatic scale of $\pm 0,05 \mathrm{~g}$ accuracy. Subsequent to measuring of carcass parts the shares of major carcass parts (breast, thighs and drumsticks) in cooled carcass of slaughtered birds were calculated.

Statistical processing of data was done using standard procedure according Snedecor and Cochran (1971). Evaluation of significance of arithmetic mean of treatments was done by t-test.

\section{Results and discussion}

Values relating to body mass prior to slaughtering, carcass yields and slaughter yields are presented in table 1 .

Based on analysis of data given in table 1, it is established that values of carcass yields »conventional processing «, »ready to roast « and »ready to grill« were very uniform between groups II and III, with addition of 0,3 and $0,6 \mathrm{mg}$ $\mathrm{Se} / \mathrm{kg}$. The lowest values for stated parameter were established in groups I $(0 \mathrm{mg} \mathrm{Se} / \mathrm{kg})$ and IV $(0,9 \mathrm{mg} \mathrm{Se} / \mathrm{kg})$. These results are in accordance with those stated by Payne and Southerm (2005), who established that addition of organic selenium had increased the carcass yield compared to inorganic source. Marković (2007) presented in his research considerably higher $(\mathrm{P}<0,05)$ carcass mass of broilers fed diets supplemented with $0,3 \mathrm{mg} / \mathrm{kg}$ of organic selenium and 100IJ of vitamin $\mathrm{E}$

By analysis of values of slaughter yields »conventional processing «, »ready to roast « and »ready to grill« it was established that there were no significant differences between investigated groups. Insignificantly higher 
values for all three dressing yields were established in group I, without addition of selenium $(83,08 \%, 75,21 \%$ and $71,21 \%)$, followed by group III with addition of $0,6 \mathrm{mg} \mathrm{Se} / \mathrm{kg}(83,02 \%, 74,66 \%$ and $70,80 \%$, respectively), whereas values in group II $(82,98 \%, 74,62 \%$ and 70,86$)$ and group IV $(82,51 \%, 74,39 \%$ and $70,67 \%$ ), with addition of 0,3 and $0,9 \mathrm{mg} \mathrm{Se} / \mathrm{kg}$ were approximately the same. Contrary to our research (where level of selenium from selenized yeast had no significant effect on dressing percentage), Edens (1997) had established the correlation between vitamin $\mathrm{E}$ and organic selenium and their effect on increase of yield in broilers. Payne and Southerm (2005), also stated some positive effects of use of organic selenium on this parameter, compared to inorganic source (sodium-selenite). Similar results are stated by Marković (2007), establishing that addition of $0,3 \mathrm{mg}$ of organic selenium and 100IJ of vitamin $\mathrm{E}$ increased considerably $(\mathrm{P}<0,05)$ yield of broiler meat.

Table 1. Yield of processed carcasses

\begin{tabular}{|c|c|c|c|c|c|c|c|c|c|}
\hline \multirow{3}{*}{ Group } & \multirow{3}{*}{ Sex } & \multirow{3}{*}{ Trait } & \multirow{3}{*}{$\begin{array}{l}\text { Body mass } \\
\text { prior to } \\
\text { slaughter } \\
\mathrm{g}\end{array}$} & \multicolumn{6}{|c|}{ Carcass } \\
\hline & & & & \multicolumn{2}{|c|}{$\begin{array}{l}\text { Conventional } \\
\text { processing }\end{array}$} & \multicolumn{2}{|c|}{ Ready to roast } & \multicolumn{2}{|c|}{ Ready to grill } \\
\hline & & & & $\begin{array}{c}\text { Mass } \\
\mathrm{g}\end{array}$ & $\begin{array}{c}\text { Dress.Perc. } \\
\%\end{array}$ & $\begin{array}{c}\text { Mass } \\
\mathrm{g}\end{array}$ & \begin{tabular}{|c|} 
Dress.Per \\
$\%$
\end{tabular} & $\begin{array}{c}\text { Mass } \\
\mathrm{g}\end{array}$ & $\begin{array}{c}\text { Dress Perc. } \\
\%\end{array}$ \\
\hline \multirow{3}{*}{ I } & \multirow{3}{*}{$\mathrm{m}+\mathrm{f}$} & $\mathrm{x}$ & 2208,75 & 1835,21 & 83,08 & 1660,87 & 75,21 & 1572,61 & 71,21 \\
\hline & & $\mathrm{Sd}$ & 87,38 & 262,33 & 0,86 & 62,91 & 1,14 & 59,38 & 1,15 \\
\hline & & $\mathrm{CV}$ & 3,96 & 14,29 & 1,04 & 3,79 & 1,52 & 3,78 & 1,61 \\
\hline \multirow{3}{*}{ II } & \multirow{3}{*}{$\mathrm{m}+\mathrm{f}$} & $\mathrm{x}$ & 2467,50 & 2048,27 & 82,98 & 1841,36 & 74,62 & 1748,57 & 70,86 \\
\hline & & $\mathrm{Sd}$ & 300,16 & 256,99 & 1,12 & 224,55 & 0,97 & 213,44 & 1,03 \\
\hline & & $\mathrm{CV}$ & 12,16 & 12,55 & 1,35 & 12,19 & 1,30 & 12,21 & 1,45 \\
\hline \multirow{3}{*}{ III } & \multirow{3}{*}{$\mathrm{m}+\mathrm{f}$} & $\mathrm{x}$ & 2479,37 & 2059,60 & 83,02 & 1851,97 & 74,66 & 1756,45 & 70,80 \\
\hline & & $\mathrm{Sd}$ & 183,89 & 170,41 & 1,01 & 151,59 & 1,13 & 148,45 & 1,31 \\
\hline & & $\mathrm{Cv}$ & 7,42 & 8,27 & 1,22 & 8,18 & 1,51 & 8,45 & 1,85 \\
\hline \multirow{3}{*}{ IV } & \multirow{3}{*}{$\mathrm{m}+\mathrm{f}$} & $\mathrm{x}$ & 2371,25 & 1957,46 & 82,51 & 1764,22 & 74,39 & 1676,05 & 70,67 \\
\hline & & $\mathrm{Sd}$ & 164,50 & 154,85 & 1,73 & 132,04 & 1,71 & 129,00 & 1,86 \\
\hline & & $\mathrm{CV}$ & 6,94 & 7,91 & 2,10 & 7,48 & 2,30 & 7,70 & 2,63 \\
\hline
\end{tabular}

Average values and variability of the mass of individual carcass parts and their share in the mass of processed carcass ready to grill are given in table 2.

Data presented in table show that the lowest breast mass was registered in group I $(573,55 \mathrm{~g})$, and the highest in group III $(657 \mathrm{~g})$. Chickens of groups II and IV (with 0,3 and $0,9 \mathrm{mg} \mathrm{Se} / \mathrm{kg}$ of food) realized breast mass of 627,90 and $633,12 \mathrm{~g}$. Compared to group I, average breast mass of chickens from groups III and IV was significantly higher $(\mathrm{P}<0,05$ and $\mathrm{P}<0,01)$. The share of breasts in percentage in the mass of processed carcass was also the highest in groups III 
and IV (37,40 and 37,86\%), and the lowest in group II (36,0\%). Share of breasts in chickens of group I was $36,47 \%$. No statistically significant differences were established between average values for share of breast in the mass of processed carcass $(\mathrm{P}>0,05)$. Similar results in regard to use of different levels of organic selenium and related to mass and share of breasts in the mass of processed carcass were obtained by Naylor et al. (2000). Inclusion of organic selenium into diet for broilers in their research has significantly increased the mass $(\mathrm{P}<$ $0,05)$ and share of breasts $(\mathrm{P}<0,05)$ in the mass of processed carcass. Marković (2007), states similar results, only the diet for broilers in this research was supplemented not only by organic selenium $(0,3 \mathrm{mg} / \mathrm{kg})$ but also vitamin $\mathrm{E}$ (100IJ).

Table 2. Yield and share of main parts in mass of cooled carcass ready to grill

\begin{tabular}{|c|c|c|c|c|c|c|c|c|}
\hline \multirow{3}{*}{ Group } & \multirow{3}{*}{ Sex } & \multirow{3}{*}{ Trait } & \multicolumn{6}{|c|}{ Carcass parts } \\
\hline & & & \multicolumn{2}{|c|}{ Breasts } & \multicolumn{2}{|c|}{ Thighs } & \multicolumn{2}{|c|}{ Drumsticks } \\
\hline & & & $\begin{array}{c}\text { Mass } \\
\mathrm{g}\end{array}$ & $\begin{array}{c}\text { Share } \\
\%\end{array}$ & $\begin{array}{c}\text { Mass } \\
\mathrm{g}\end{array}$ & $\begin{array}{c}\text { Share } \\
\%\end{array}$ & $\begin{array}{c}\text { Mass } \\
\mathrm{g}\end{array}$ & $\begin{array}{c}\text { Share } \\
\%\end{array}$ \\
\hline \multirow{3}{*}{ I } & \multirow[t]{3}{*}{$\mathrm{m}+\mathrm{f}$} & $\mathrm{x}$ & $573,55^{\mathrm{aA}}$ & 36,47 & 221,95 & 14,11 & $252,02^{\mathrm{a} A}$ & 16,02 \\
\hline & & $\mathrm{Sd}$ & 31,03 & 1,33 & 15,35 & 0,74 & 16,73 & 1,07 \\
\hline & & $\mathrm{Cv}$ & 5,41 & 3,65 & 6,92 & 5,28 & 6,64 & 6,68 \\
\hline \multirow{3}{*}{ II } & \multirow[t]{3}{*}{$\mathrm{m}+\mathrm{f}$} & $\mathrm{x}$ & $627,90^{\mathrm{ab}}$ & 36,00 & 252,84 & 14,40 & $289,80^{\mathrm{b}}$ & 16,63 \\
\hline & & $\mathrm{Sd}$ & 67,99 & 1,64 & 40,17 & 0,73 & 27,63 & 0,63 \\
\hline & & $\mathrm{Cv}$ & 10,83 & 4,55 & 15,89 & 5,07 & 9,53 & 3,79 \\
\hline \multirow{3}{*}{ III } & \multirow[t]{3}{*}{$\mathrm{m}+\mathrm{f}$} & $\mathrm{x}$ & $657,00^{\mathrm{B}}$ & 37,40 & 246,22 & 13,98 & $292,03^{\mathrm{B}}$ & 16,62 \\
\hline & & $\mathrm{Sd}$ & 59,09 & 0,99 & 28,89 & 0,60 & 27,30 & 0,67 \\
\hline & & $\mathrm{CV}$ & 8,99 & 2,65 & 11,73 & 4,29 & 9,34 & 4,03 \\
\hline \multirow{3}{*}{ IV } & \multirow[t]{3}{*}{$\mathrm{m}+\mathrm{f}$} & $\mathrm{x}$ & $633,12^{b}$ & 37,86 & 239,71 & 14,28 & $277,61^{\mathrm{ab}}$ & 16,53 \\
\hline & & $\mathrm{Sd}$ & 39,07 & 1,87 & 23,56 & 0,38 & 30,03 & 0,78 \\
\hline & & $\mathrm{Cv}$ & 6,17 & 4,94 & 9,83 & 2,66 & 10,82 & 4,72 \\
\hline
\end{tabular}

Differences between $a$ and $b$ are significant on level $\mathrm{P}<0,05$

Differences between A and B are significant on level $\mathrm{P}<0,01$

The greatest average mass of thighs $(252,84 \mathrm{~g})$ was established in chickens fed diet with $0,3 \mathrm{mg} \mathrm{Se} / \mathrm{kg}$, whereas the chickens of the first group fed diet without supplemented selenium had the lowest mass of thighs $(221,95 \mathrm{~g})$. In chickens of groups III and IV (with 0,6 and $0,9 \mathrm{mg} \mathrm{Se} / \mathrm{kg}$ of food) established values for thigh mass were slightly lower than in chickens of group II $(246,22$ and $239,71 \mathrm{~g}$ ), which is by 10,93 and $8,0 \%$ higher compared to group I. Average share of thighs in the mass of processed carcass was approximately the same in all investigated groups. The highest $(14,4 \%)$ was established in chickens of 
group II, and the lowest $(13,98 \%)$, in chickens of investigation group III. Established values in groups I and IV of chickens were 14,33 and 14,28\%.

If data for average mass of drumsticks is analyzed, it is registered that chickens fed selenium in their diet $(0,3,0,6$ and $0,9 \mathrm{mg} / \mathrm{kg})$ had realized the best results $(289,8,292,03$ and $277,61 \mathrm{~g})$. Values established in chickens of groups II and III were considerably higher $(\mathrm{P}<0,05$ and $\mathrm{P}<0,01)$, by 14,99 and $15,87 \%$ respectively, compared to chickens I. The same can be said for the share of drumsticks in the mass of processed carcass, since their share in percentage was higher (by 3,80,3,74 and 3,18\%) in chickens fed diets with addition of this microelement compared to chickens of group I, but established differences weren't statistically significant $(\mathrm{P}>0,05)$.

\section{Conclusion}

Based on obtained results for slaughter properties of broiler meat realized in this research, the following can be concluded:

1. Average values for carcass yields »conventional processing «, »ready to roast « and »ready to grill« were very uniform between groups II and III (with addition of 0,3 and $0,6 \mathrm{mg} \mathrm{Se} / \mathrm{kg}$ ). The lowest values for stated parameter were determined in group I $(0 \mathrm{mg} \mathrm{Se} / \mathrm{kg})$ and group IV $(0,9 \mathrm{mg} \mathrm{Se} / \mathrm{kg})$.

2. Average values for slaughter yields »conventional processing «, »ready to roast « and »ready to grill«) were approximately same in chickens of all investigation groups, and established results weren't statistically significant $(\mathrm{P}>0,05)$.

3. The lowest breast mass was in group I $(573,55 \mathrm{~g})$, and the highest in group III $(657 \mathrm{~g})$. Chickens of groups II and IV (with 0,3 and $0,9 \mathrm{mg}$ $\mathrm{Se} / \mathrm{kg}$ of food) realized breast mass of 627,90 and 633,12g. Compared to group I, average breast mass of chickens in groups III and IV was significantly higher $(\mathrm{P}<0,05$ and $\mathrm{P}<0,01)$.

4. The share of breasts in percentage in mass of processed carcass was the highest in groups III and IV (37,40 and 37,86\%), and the lowest in group II $(36,0 \%)$. Share of breasts in chickens of group I was $36,47 \%$. Between average values for share of breasts in the mass of processed carcass no significant statistical differences were established $(P>0,05)$.

5. The highest average thigh mass $(252,84 \mathrm{~g})$ was established in chickens fed diets with $0,3 \mathrm{mg} \mathrm{Se} / \mathrm{kg}$ (II group), whereas chickens of the first group fed mixture without addition of selenium had the lowest thigh mass $(221,95 \mathrm{~g}$ ). Chickens of groups III and IV (with 0,6 and $0,9 \mathrm{mg}$ 
Se/kg of food) had by 10,93 and $8,0 \%$ higher mass of thighs compared to group I.

6. The highest value $(14,4 \%)$ for average share of thighs in the mass of processed carcass was established in chickens of group II, and the lowest $(13,98 \%)$ in chickens of group III. Established values in groups I and IV were 14,33 and $14,28 \%$.

7. Mass of drumsticks in chickens of groups II and III was by 14,99 and $15,87 \%$ higher than in chickens of group I $(\mathrm{P}<0,05$ and $\mathrm{P}<0,01)$.

8. Addition of organic selenium in the form of selenized yeast $(0,3,0,6$ and $0,9 \mathrm{mg} / \mathrm{kg}$ ) in the food for fattening chickens increased the share of drumsticks in the mass of processed carcass (by 3,80, 3,74 and 3,18\%) compared to chickens of the first group $(\mathrm{P}>0,05)$.

\title{
UTICAJ RAZLIČITIH NIVOA ORGANSKOG SELENA NA KLANICNE OSOBINE BROJLERA
}

\author{
Ž. Jokić, Z. Pavlovski, S. Mitrović, V. Đermanović
}

\section{Rezime}

Ispitivan je uticaj različitih nivoa organskog selena (selenizirani kvasac) na klanične osobine mesa tovnih pilića (brojlera). Ogled je izveden na 120 pilića provenijence Hybro-PN podeljenih u četiri grupe, u trajanju od šest nedelja. Sve grupe pilića hranjene su potpunim smešama, a selen je dodavan u hranu u formi seleniziranog kvasca u količini od 0 (I ); 0,3 (II); 0,6 (III) ili $0,9 \mathrm{mg} / \mathrm{kg}$ (IV-grupa).

Najveće prosečne vrednosti za prinos trupova »standardna obrada«, »spremno za pečenje« i »spremno za roštilj« imali su pilići III grupe $(2059,6$, $1851,97$ i $1756,45 \mathrm{~g})$, sa dodatkom $0,6 \mathrm{mg}$ Se/kg. Zatim sledi II $(2048,17$, $1841,36$ i $1748,57 \mathrm{~g})$ i IV grupa $(1957,46,1764,22$ i $1676,05 \mathrm{~g})$ sa 0,3 i $0,9 \mathrm{mg} / \mathrm{kg}$ dodatog selena, dok su najmanje vrednosti $(1835,21,1660,87$ i 1572,61g) ustanovljene u I grupi bez dodatka ovog mikroelementa.

Prosečne vrednosti za klanične randmane (»standardna obrada«, »spremno za pečenje« i »spremno za roštilj« su bile približno iste kod pilića svih ispitivanih grupa, a utvrđene razlike nisu pokazale statističku značajnost ( $\mathrm{P}$ $>0,05)$.

Najmanja masa grudi bila je u I grupi $(573,55 \mathrm{~g})$, a najveća u III $(657 \mathrm{~g})$. Pilići II i IV grupe (sa 0,3 i $0,9 \mathrm{mg} \mathrm{Se} / \mathrm{kg}$ hrane) ostvarili su masu grudi od 
627,90 i $633,12 \mathrm{~g}$. U odnosu na I grupu, prosečna masa grudi pilića III i IV grupe bila je značajno veća $(\mathrm{P}<0,05$ i $\mathrm{P}<0,01)$.

Udeo grudi u masi očišćenog trupa bio je najveći u III i IV grupi $(37,40$ i $37,86 \%)$, a najmanji u II (36,0\%). Kod pilića I grupe navedena vrednost je iznosila je $36,47 \%$.

Prosečan udeo bataka u masi očišćenog trupa bio je približno isti kod svih ispitivanih grupa. Najveća vrednost $(14,4 \%)$ ustanovljena je kod pilića II, a najmanja $(13,98 \%)$, kod pilića III ispitivane grupe.

Pilići koji su u hrani dobijali organski selen $(0,3,0,6$ i $0,9 \mathrm{mg} / \mathrm{kg})$ imali su za 3,80, 3,74 i 3,18\% veći udeo karabataka u masi očišćenog trupa u odnosu na piliće I grupe.

Ključne reči: pilići selenizirani kvasac, klanične osobine

\section{References}

AHN, C.N., CHAE, H.S. ET AL. (1998): Effects of full fat flax seed, $\alpha$ tocopherol, ascorbic acid and selenium on storage of broiler meats. Journal of Livestock Science, 40: 96-102.

BURK, R.F. (1983): Biological availability of selenium. Ann. Rev. Nutr., 3:5370.

CANTOR, A.H. AND J.Z. TARINO (1982): Comparative effects of inorganic and organic dietary sources of selenium on selenium levels and seleniumdependent glutathione peroxidase activity in blood of young turkeys. J. Nutr. 112:2187-2196.

CANTOR, A.H., C.D. SUTTON AND J.H. JOHNSON (1983): Biological availability of selenodicysteine in chicks. Poult. Sci. 62:2429-2432.

COLNAGO, G.J., JENSEN, L.S., LONG, P.L. (1984): Effects of selenium and vitamin $\mathrm{E}$ on the development of immunity to coccidiosis in chickens. Poult. Sci., 63:1136-1143.

COMBS, G.F. Jr. (1977): Biohemical functions and importance in poultry nutrition. Proceedings, Georgia Nutrition Conference for Feed Industry 2-15.

COMBS, G.F. JR., COMBS, S.B. (1986): The role of selenium in nutrition. Academic Press, Inc., New York, NY.

DOWNS, K.M., J.B. HESS AND S.F. BILGILI (2000): Selenium source effect on broiler carcass characteristics, meat quality, and drip loss. J. Appl. Anim. Res., 18: 61-72. 
DŽINIĆ N., TOMOVIĆ, V., PETROVIĆ LJ., PERIĆ L. (2006): Uticaj dodatka selena različitog porekla $\mathrm{u}$ hranu za piliće na kvalitet $\mathrm{m}$. Pectoralis. Tehnologija mesa, 47, 5-6, 199-203.

EDENS, F.W. (1996): Organic selenium: from feathers to muscle integrity to drip loss. Five years onward: no more selenit! In: Biotechnology in the Feed industry. Proceedings of 12th Alltech's Annual Symposium, Edited by LYONS, T.P., JACQUES, K.A., Nottingham University Press, Nottingham, UK, pp. 165-185.

EDENS, F.W. (1997): Potential for organic selenium to replace, selenite, in poultry diets. Zootecnica International 20: 28-31.

EDENS, F.W. (2001): Involvement of Sel-Plex in physiolical stability and performance of broiler chickens. In: Biotechnology in the Feed industry. Proceedings of 17th Alltech's Annual Symposium, Edited by Lyons, T.P. and Jacques, K.A., Nottingham University Press, Nottingham, UK, pp. 349376.

HASSAN, S. (1987): Bioavialability of selenium in feedsuffs as studied in the chicks. Swedish University of Agricultural science, 1-65.

J.S, J.F. (1985): Biological availability of selenium and phosphorus in fish meal as affected by condition of fish and typeof meal. Brit. Poult. Sci., 26:289-297.

JOKIĆ, Ž. JOKSIMOVIĆ-TODOROVIĆ, M V. DAVIDOVIĆ (2005): Organski selen u ishrani pilića u tovu. Biotehnologija u stočarstvu, Vol. 21, str. 79-89.

MAHAN, D.C. (1999): Organic selenium: using natures model to redefine selenium suplemention for animals. In: Biotehnology in the Feed Industry. Proccedings of the $15^{\text {th }}$ Annual Symposium (T.P. Lyons and K.A. Jacqueseds. Nottingham University Press).

MARKOVIĆ R.(2007): Uticaj selena organskog i neorganskog porekla i različite količine vitamina $\mathrm{E}$ na proizvodne rezultate i kvalitet mesa brojlera. Doktorska disertacija odbranjena na Fakultetu veterinarske medicine u Beogradu.

MARTELLO, M.A. AND J.D. LATSHAW (1982): Utilization of dietary selenium as indicated by prevention of selenium deficiency and by retention in eggs. Nutr. Rep. Int. 26:43.

MIHAILOVIĆ, M., TODOROVIĆ M., ILIĆ, V. (1991): Effect of dietary selenium of glutathione peroxidase activity and body weight of growing turkeys. Acta Vet., 23:75-80.

NAYLOR, A.J., CHOCT, M. AND K.A. JACQUES (2000): Effect of feeding Sel-Plex ${ }^{\text {TM }}$ Organic Selenium in Diets of Broiler Chickens on Liver Selenium Concentrations. Southern Poultry Science, Atlanta, Georgia.

OSMAN, M. AND J.D. LATSHAW (1976): Biological potency of seleniumfrom sodium selenite, selenomethionine and selenocystine in the chick. Poult. Sci. 55:987. 
PAYNE, R.L. AND SOUTHERM, L.L. (2005): Comparison of Inorganic and Organic Selenium Sources for Broilers. Poultry Science 84, 898-902. POTTER, L.M. AND J.R. SHELTON (1976): Dried Whey Product, Menhaden Fish Meal, Methionine and Erythromycin in Diets of Young Tukeys. Poult. Sci. 55:2117-2127.

POTTER, L.M., J.R. SHELTON AND C.M. PARSONS (1980): The unidentified growth factor in menhaden fish meal. Poult. Sci. 59:128-134.

ROTRUCK, J.T., POPE, A.L. ET AL. (1973): Selenium. Biohemical role as a component of glutathione peroxidasse. Science, 179:588-590.

SURAI, P.F. (1999): Novi način definisanja potreba u selenu korišćenjem prirodnog modela - Our Industry Under the Microskope Biotehnology Responds. 13 Evropska, Bliskoistočna i Afrička serija predavanja. Hotel Interkontinental 2 mart, 1999.

SURAI, P.F. (2000): Organic selenium: beneficts to animals and humans, a biochemist's view. In: Biotehnology in the Feed Industry. Proccedings of Alltech's $16^{\text {th }}$ Annual Symposium (T.P. Lyons and K.A. Jacques eds. Nottingham University Press).

SURAI, P.F. (2002): Natural antioxidants in Avian Nutrition and Reproduction. Nottingham University Press.

SURAI, P.F. AND DVORSKA, J.E. (2002): Effect of selenium and vitamin E content of the diet on lipid peroxidation in breast muscle tissue of broiler breeder hens during storage. Proceedings of Australian Poultry Science Symposium 14: 187-192.

THOMPSON, J.N. AND SCOTT, M.L. (1969): Role of selenium in the nutrition of the chick. J. Nutr. 97:335-342.

TODOROVIĆ M. (1990): Uticaj deficita selena na aktivnost glutation peroksidaze, alkalne fosfataze i prirast ćurića u tovu. Magistarski rad odbranjena na Fakultetu veterinarske medicine u Beogradu.

TODOROVIĆ M. (1997): Toksičnost selena kod pilića u tovu. Doktorska disertacija odbranjena na Fakultetu veterinarske medicine u Beogradu.

TODOROVIĆ M., MIHAILOVIĆ, M., HRISTOV, S. (1999): Effect of excessive levels of sodium selenite on daily weight gain, mortality and plasma selenium in chickens. Acta Vet., vol. 49 No 5-6:313-320. 